\title{
DECISIONS
}

\section{Painful testicle in a young boy}

\author{
Stephen M. Graham MD, John M. Gatti MD
}

Previously published at www.cmaj.ca

A 12-year-old boy presents to his primary care physician with a three-hour history of severe pain on the right side of his scrotum. Examination shows the right side of the scrotum to be swollen, red and very tender. The right cremasteric reflex is absent.

\section{What diagnosis should be considered?}

The primary diagnoses to consider are testicular torsion, torsion of a testicular appendage and epididymitis. ${ }^{1-3}$ Other less common diagnoses include a hernia or hydrocele, scrotal cellulitis and idiopathic scrotal edema ${ }^{1-3}$ (Box 1). Testicular torsion must be identified quickly, because there is only a fourto eight-hour window before serious ischemic damage occurs that can potentially affect production of sperm and viability of the testicle. ${ }^{4}$

\section{Does the patient have testicular torsion?}

Clues to the diagnosis can be found in the patient's history and on physical examination. Timing is important: most patients with torsion of the testicle or appendage (60\%-70\%) present within 12 hours after the onset of pain, whereas those with epididymitis present after 12 hours. ${ }^{3}$ There could be a history of episodes of similar pain with all three conditions. Nausea and vomiting are usually associated with torsion of the testicle or appendage, whereas dysuria and fever are more common with epididymitis. ${ }^{2,3}$

A swollen and erythematous hemiscrotum could occur with all three conditions, depending on how long the symptoms have been present. With testicular torsion, tenderness is usually diffuse, and the testis may lie in a horizontal or elevated position. The cremasteric reflex (created by lightly stroking the superomedial aspect of the thigh to detect elevation of the ipsilateral testis within the scrotum [normal response]) is one of the more accurate predictors of testicular torsion, but its absence or presence is not diagnostic., ${ }^{2,3}$ With epididymitis, tenderness is often localized to the epididymis; the cremasteric reflex is typically intact. The "blue dot sign" - a blue mass seen through the scrotal skin and usually palpable early - can be detected about $23 \%$ of the time in a patient with torsion of a testicular appendage. ${ }^{3}$

\section{What tests are required?}

Additional testing may be necessary if the diagnosis is unclear from the patient's history and the results of physical examination (Table 1). A urinalysis showing pyuria and

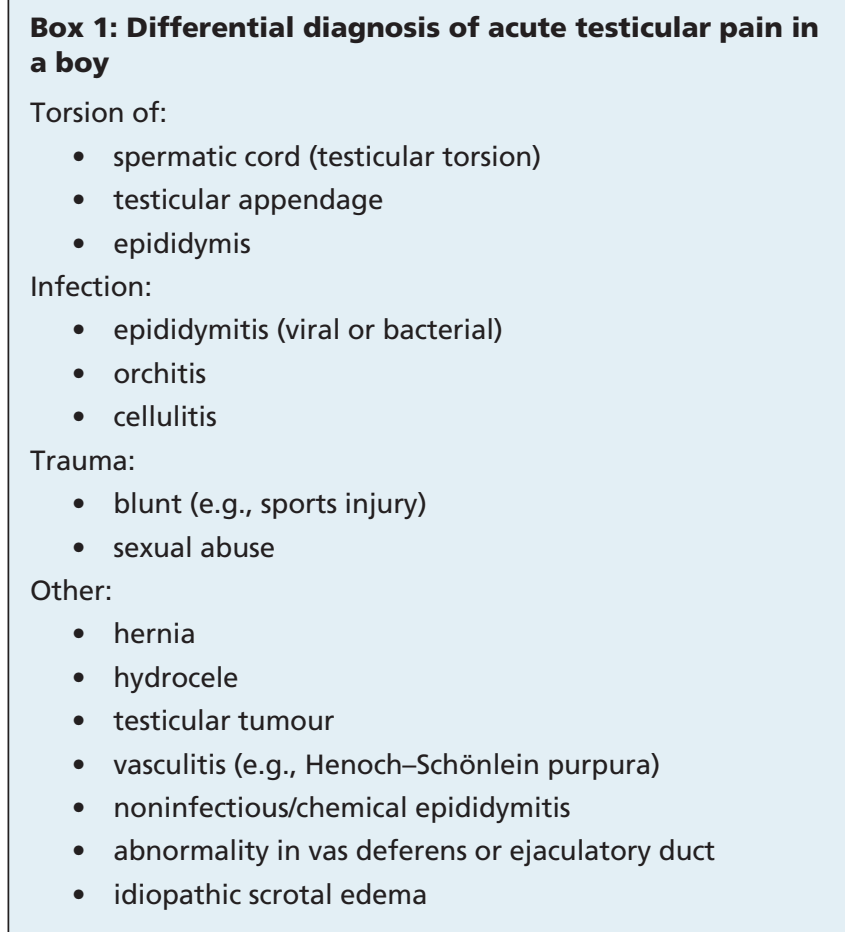

bacteria is more diagnostic of epididymitis than of either form of torsion. ${ }^{3}$ A urethral swab should be taken for culture from sexually active males, especially if urethral discharge is present.

High-resolution colour-flow Doppler ultrasonography has replaced radionuclide imaging for patients with acute scrotal pain because it is more available, has a shorter testing time, can determine blood flow, and eliminates exposure to ionizing radiation. The results typically show no blood flow within an enlarged, often heterogenous testicle in testicular torsion; a discrete appendage (early) or increased blood flow to the testis or epididymis (late) in torsion of an appendage; and increased blood flow to an enlarged epididymis, often with thickening of the scrotal wall in epididymitis. In experienced hands, this type of ultrasonogra-

From the Department of Urology (Graham), University of Kansas Medical Center; and the Department of Pediatric Surgery, Section of Pediatric Urology (Gatti), Children's Mercy Hospitals and Clinics, Kansas City, USA

CMAJ 2010. DOI:10.1503/cmaj.090499 
Table 1: Guide to acute testicular pain in a boy

\begin{tabular}{|c|c|c|c|c|c|}
\hline Diagnosis & $\begin{array}{l}\text { Usual duration of } \\
\text { pain before } \\
\text { evaluation, } h\end{array}$ & Location of pain & $\begin{array}{c}\text { Results of } \\
\text { urinalysis } \\
\text { (pyuria and/or } \\
\text { bacteria) }\end{array}$ & $\begin{array}{c}\text { Results of } \\
\text { ultrasonography }\end{array}$ & Management* \\
\hline $\begin{array}{l}\text { Testicular } \\
\text { torsion }\end{array}$ & $<12$ & Testis & Negative & $\begin{array}{l}\text { No blood flow to } \\
\text { testis }\end{array}$ & Referral to urologist \\
\hline $\begin{array}{l}\text { Torsion of a } \\
\text { testicular } \\
\text { appendage }\end{array}$ & $<12$ & $\begin{array}{c}\text { Localized to } \\
\text { appendage (early) } \\
\text { Diffuse (late) }\end{array}$ & Negative & $\begin{array}{l}\text { Normal to } \\
\text { increased blood } \\
\text { flow to testis with } \\
\text { enlarged testis } \\
\text { appendage }\end{array}$ & $\begin{array}{l}\text { NSAIDs } \\
\text { Scrotal support } \\
\text { Limited activity }\end{array}$ \\
\hline Epididymitis & $>12$ & Epididymis & Positive & $\begin{array}{l}\text { Normal to } \\
\text { increased blood } \\
\text { flow to testis with } \\
\text { increased flow to } \\
\text { epididymis }\end{array}$ & $\begin{array}{l}\text { NSAIDs } \\
\text { Scrotal support } \\
\text { Limited activity } \\
\text { Antibiotics if indicated }\end{array}$ \\
\hline
\end{tabular}

*Note: NSAIDs = nonsteroidal anti-inflammatory medications.

phy has a sensitivity of $89.9 \%$, a specificity of $98.8 \%$ and a false-positive rate of $1 \%{ }^{1}$

If testicular torsion is suspected on the basis of the clinical history and the results of physical examination, one should avoid imaging because it will delay surgical exploration. ${ }^{1}$ A patient with suspected testicular torsion should immediately be referred to a surgeon.

\section{What if the patient doesn't have testicular torsion?}

Management of nonbacterial epididymitis and torsion of a testicular appendage includes nonsteroidal anti-inflammatory medications, scrotal support and limited activity. In epididymitis, antibiotics should only be given if there is a high suspicion of bacterial involvement (e.g., urinalysis shows pyuria or bacteria, or urethral discharge). ${ }^{5}$ Patients eight years of age or older in whom gonococcal or chlamydial epididymitis is suspected should be given one 250-mg dose of intramuscular ceftriaxone and $100 \mathrm{mg}$ of doxycycline, twice daily for seven days. Treatment for epididymitis when a gonococcal culture or a nucleic acid amplification test yields negative results or when the disorder is caused by enteric organisms (Escherichia coli) is levofloxacin, $500 \mathrm{mg}$ a day for 10 days. ${ }^{6}$ Patients with epididymitis or torsion of a testicular appendage should be counseled to phone or return if the symptoms become worse or last more than one week. In these conditions, however, the pain, is generally self-limited.

\section{The case revisited}

The urologist was consulted for suspicion of testicular torsion. The patient was taken to the operating room within the next hour; exploration of the scrotum revealed an ischemic right testicle with a bell-clapper deformity (i.e., testis attached to a free-hanging vascular pedicle). Manual detorsion (rotation of the testicle to untwist the spermatic cord) restored blood flow, and the testis was saved. The testis was fixed to the scrotum in three places, as was the contralateral testis, which also shared the bell-clapper deformity, to prevent torsion.

This article has been peer reviewed.

Competing interests: None declared.

\section{REFERENCES}

1. Baker LA, Sigman D, Mathews RI, et al. An analysis of clinical outcomes using color Doppler testicular ultrasound for testicular torsion. Pediatrics 2000;105:604-7.

2. Ciftci AO, Senocak ME, Tanyel FC, et al. Clinical predictors for differential diagnosis of acute scrotum. Eur J Pediatr Surg 2004;14:333-8.

3. Kadish HA, Bolte RG. A retrospective review of pediatric patients with epididymitis, testicular torsion, and torsion of testicular appendages. Pediatrics 1998;102:73-6.

4. Bartsch G, Frank S, Marberger H, et al. Testicular torsion: late results with special regard to fertility and endocrine function. J Urol 1980;124:375-8.

5. Lau P, Anderson PA, Glacomantonio JM, et al. Acute epididymitis in boys: Are antibiotics indicated? Br J Urol 1997;79:797-800.

6. Updated recommended treatment regimens for gonococcal infections and associated conditions - United States, April 2007. Atlanta (GA): Centers for Disease Control and Prevention; 2007. Available: www.healthandwelfare.idaho.gov /LinkClick.aspx?fileticket=bVN\%2B6yP1tIY\%3D\&tabid=179\&mid=1460 (accessed 2010 Feb. 5).

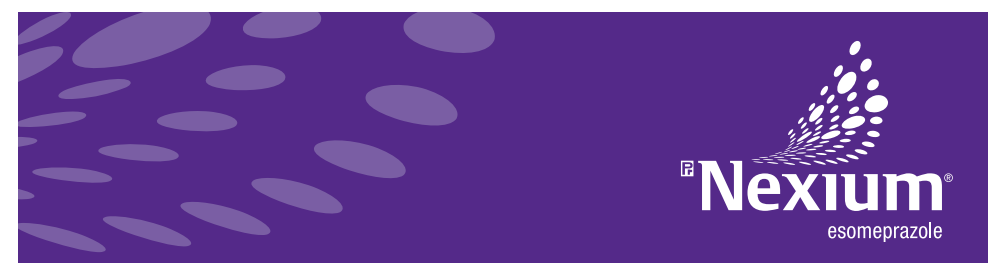

